\title{
Fate of organic carbon released from decomposing copepod fecal pellets in relation to bacterial production and ectoenzymatic activity
}

\author{
Peter Thor ${ }^{1,3, *}$, Hans G. Dam², Daniel R. Rogers ${ }^{2}$ \\ ${ }^{1}$ Department of Life Sciences and Chemistry, Roskilde University, Universitetsvej 1, 4000 Roskilde, Denmark \\ ${ }^{2}$ University of Connecticut, Department of Marine Sciences, 1080 Shennecossett Road, Groton, Connecticut 06340, USA
}

${ }^{3}$ Present address: Kristineberg Marine Research Station, 45034 Fiskebäckskil, Sweden

\begin{abstract}
Fecal pellets were produced by Acartia tonsa fed ${ }^{14} \mathrm{C}$-labeled diatom, cryptophyte, and dinoflagellate diets, and were incubated in $1.2 \mu \mathrm{m}$-filtered Long Island Sound seawater. Based on the ${ }^{14} \mathrm{C}$ label, the decrease in fpOC (fecal pellet organic carbon), the release and fate of dissolved organic carbon (DOC) and particulate organic carbon (POC), as well as bacterial production and enzymatic activity, were followed over a $96 \mathrm{~h}$ period. fpOC decreased by 9,14 , and $19 \% \mathrm{~d}^{-1}$ in diatom, cryptophyte, and dinoflagellate pellets, respectively. There was a fast, possibly passive, leakage of DOC from pellets from all 3 diets within a few hours after egestion, which may not have been utilized by attached

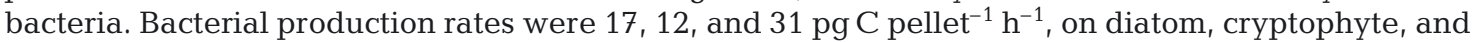
dinoflagellate pellets, respectively. These were 5 orders of magnitude higher than production rates of free-living bacteria, indicating that copepod fecal pellets are hot spots of pelagic microbial production. The high production was caused primarily by high initial bacterial abundances. Accordingly, production and growth were entirely uncoupled in diatom pellets. There were no increases in abundance of attached bacteria on any of the 3 diets, indicating that the produced bacterial cells were released from the fecal pellets. Attached bacteria had a higher ectoenzymatic activity than free-living bacteria, but their production and ectoenzymatic activity were uncoupled and they only assimilated a minor fraction of the released DOC. DOC was therefore released favoring free-living microbes. The chitinase activity, which increased several-fold, was coupled to the production of attached bacteria; thus, chitin may play an important role in bacterial production on copepod fecal pellets.
\end{abstract}

KEY WORDS: Copepod fecal pellets $\cdot$ Fecal pellet decomposition $\cdot$ Pelagic DOC flux $\cdot$ Pelagic POC flux $\cdot$ Attached bacterial production $\cdot$ Ectoenzymatic activity

\section{INTRODUCTION}

Fecal pellets originating from mesozooplankton constitute an important pool of particulate organic matter in the epipelagic ocean. Although fecal pellet in some cases constitute a significant fraction of the sedimenting organic carbon (Gonzalez et al. 1994, Landry et al. 1994), they typically contribute less to the sedimentary flux than other sources (Fowler et al. 1991, Wassmann et al. 1999, Roy et al. 2000). Accordingly, many studies report low contributions from fecal pellets to the lower ocean proper (Bathmann et al. 1987, Lane et al. 1994, Lundsgaard \& Olesen 1997) even with high secondary production in the euphotic zone (Ayukai \& Hattori 1992, Viitasalo et al. 1999). However, the significance of zooplankton fecal pellets extends well beyond the question of carbon sequestration. The disparity between fecal pellet production and contribution to the sedimentary flux is partly a function of the recycling of organic matter originating from fecal pellets. It is now generally believed that organic matter originating from fecal pellet produced by small copepods is re- 
cycled (Wotton \& Malmqvist 2001, Turner 2002) and that most carbon originating from these fecal pellets remains part of the long-lived organic carbon in the epipelagic (Legendre \& Michaud 1998). Hence, the role of fecal pellets from small copepods is that of supplying nutrients to the epipelagic planktonic microbial community rather than maintaining the vertical flux of organic matter.

Copepod fecal pellets host an extensive flora of attached bacteria (Gowing \& Silver 1983, Bianchi et al. 1992, Delille \& Razouls 1994, Hansen \& Bech 1996). Breakdown of the fecal pellets is in part governed by microbial decomposition driven by the hydrolytic activity of these bacteria. The potential hydrolytic activity is generally high in pelagic aggregates of organic matter (Karner \& Herndl 1992, Smith et al. 1992), and if this potential is fully exploited in fecal pellets, then decomposition and hence recycling of organic matter may occur rapidly. The fate of the hydrolyzed organic compounds can be manyfold. For example, the organic matter can be incorporated into attached bacteria, thereby remaining associated with the fecal pellets. Conversely, the rates of hydrolytic activity and production of attached bacteria may be uncoupled (Smith et al. 1992), resulting in the release of DOC. This might nurture the growth of nonattached free living bacteria and protozoans (Cho \& Azam 1988).

In the present study we investigated the fate of fecal pellet organic matter in relation to ectoenzymatic activity and growth of attached bacteria. Using the approach of Hansen et al. (1996), we studied the decomposition of fecal pellets produced by Acartia tonsa fed on 3 different algal diets that represented the phytoplankton succession through a typical spring-summer season in temperate waters: Thalassiosira weissflogii represented a spring diatom bloom situation, the cryptophyte Rhodomonas lens the summer phytoplankton dominated by nanoflagellates, and Prorocentrum minimum a late-summer dinoflagellate bloom.

\section{MATERIALS AND METHODS}

Production and labeling of fecal pellets. Strains of Thalassiosira weissflogii, Rhodomonas lens, and Prorocentrum minimum were kept in the exponential growth phase in f/2 medium (Guillard \& Ryther 1962) on an 18:6 h light:dark cycle at $16^{\circ} \mathrm{C}$ and $34 \%$ S. Silica was added to $T$. weissflogii, and $R$. lens was bubbled gently to maintain exponential growth. Prior to the experiments, the algae were diluted with $\mathrm{f} / 2$ medium and $600 \mu \mathrm{Ci} \mathrm{Na}{ }^{14} \mathrm{CO}_{3} \mathrm{l}^{-1}$. They were then grown for at least 4 generations to ensure uniform isotope labeling (Nielsen \& Olsen 1989).
Specimens of the copepod Acartia tonsa were caught in Long Island Sound and kept in culture on a mixture of the 3 algal species in dim daylight conditions at $20^{\circ} \mathrm{C}$ and $34 \%$ S. Adult copepods and late copepodites from this culture were acclimated with the algal species used in the experiments for $24 \mathrm{~h}$. Approximately 500 acclimated copepods were then retrieved on a $200 \mu \mathrm{m}$ monofilament screen and placed in two $5 \mathrm{l}$ beakers holding the labeled algae $\left(500 \mu \mathrm{g} \mathrm{C}^{-1}\right)$. Screen insets (200 $\mu \mathrm{m}$ mesh-size) at the bottom allowed fecal pellets to escape coprophagy. Gentle bubbling kept the algae in suspension. The copepods were then allowed to feed on the labeled algae for $6 \mathrm{~h}$, a sufficiently long period to ensure complete evacuation of unlabeled material from the gut (Dam \& Peterson 1988). Unlabeled fecal pellets were removed and the copepods were re-introduced to the labeled algae at the same concentration. After 3 to $5 \mathrm{~h}$ the labeled fecal pellets were retrieved on a $30 \mu \mathrm{m}$ screen. The fecal pellets were then washed with $0.5 \mu \mathrm{m}$ filtered seawater (fsw) twice to remove any dissolved label and transferred to fsw in sterilized petri dishes.

Water for the experiments was collected at $4 \mathrm{~m}$ depth in Long Island Sound and filtered through $1.2 \mu \mathrm{m}$ glassfiber filters (filtered LIS water), and 100 labeled and intact fecal pellets were mouth-pipetted from the petri dishes into sterilized vials holding $10 \mathrm{ml}$ of this water. Pasteur pipettes drawn out over a flame to obtain an opening not much larger than the fecal pellets themselves were used for the pipetting. The accuracy of the pipetting procedure was $5 \%$. This was tested by counting the pipetted fecal pellets. We incubated 3 replicates for carbon release measurements and 3 replicates for bacterial production measurements for $0,12,24,48$, and $96 \mathrm{~h}$, respectively. All vials were placed on a tilting table rotating gently at $30 \mathrm{rpm}$ to mimic water movement around sinking fecal pellets. The water movement was gentle enough to avoid mechanical breaking of the fecal pellets but sufficient to ensure total mixing of the water in the vials within a few minutes; this was tested with dye. To determine the direct contribution of dissolved ${ }^{14} \mathrm{C}$-label from the copepod culture, 3 replicate controls of the same volume but without fecal pellets were pipetted directly into scintillation vials and measured by liquid scintillation.

Carbon release. After the incubation, all samples were preserved by pipetting $600 \mu \mathrm{l}$ of $34 \%$ formaldehyde into the vials to a final concentration of $2 \%$. The samples were then split into $2 \mathrm{ml}$ aliquots containing fecal material (fecal pellet aliquots) and $5 \mathrm{ml}$ aliquots containing no visually discernible fecal material (non-fecal pellet aliquots). This was done by pipetting $8 \mathrm{ml}$ from the vials holding the preserved samples into a petri dish without disturbing the fecal pellets at the bottom of the vials, examination at $40 \times$ magnification for fecal remnants, and 
pipetting a $5 \mathrm{ml}$ aliquot of this $8 \mathrm{ml}$ sample into other vials. All aliquots were filtered through $0.45 \mu \mathrm{m}$ cellulose acetate filters at low suction to allow measurement of $\mathrm{PO}^{14} \mathrm{C}$ (filter) and $\mathrm{DO}^{14} \mathrm{C}$ (filtrate) by liquid scintillation counting after dissolving filters in ethyl acetate. The fecal pellets were thus retrieved on $0.45 \mu \mathrm{m}$ filters, which should have avoided damage. The organic carbon content of these 4 fractions ( $\mathrm{ng} \mathrm{C} \mathrm{ml}{ }^{-1}$ ) was calculated by dividing the isotopic activity of the samples (disintegrations $\mathrm{min}^{-1} \mathrm{ml}^{-1}: \mathrm{dpm} \mathrm{ml} \mathrm{m}^{-1}$ ) with the specific activity of

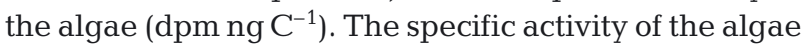
was calculated by dividing the specific activity of a $1 \mathrm{ml}$ sample of labeled algae of a known concentration filtered onto GF/F filters (dpm cell ${ }^{-1}$ ) by values of carbon content (pg C cell ${ }^{-1}$ ). Carbon contents where either obtained from previous CHN analysis or from measurements of equivalent spherical diameter and carbon to volume ratio (Strathmann 1967, Besiktepe \& Dam 2002). Thus, 4 different fractions of organic carbon were obtained in each sample: $\mathrm{DOC}_{\mathrm{p}}$ (ng DOC $\mathrm{m}^{-1}$ in fecal pellet aliquots), $\mathrm{POC}_{\mathrm{p}}$ (ng $\mathrm{POC} \mathrm{ml} \mathrm{C}^{-1}$ in fecal pellet aliquots), $\mathrm{DOC}_{\mathrm{w}}$ (ng DOC ml ${ }^{-1}$ in non-fecal pellet aliquots), $\mathrm{POC}_{\mathrm{w}}$ (ng POC ml-1 in non-fecal pellet aliquots).

These fractions were used to calculate the release and fate of the original fecal pellet organic carbon (in ng $\mathrm{C}$ pellet ${ }^{-1}$ ). The 3 different carbon pools were calculated as:

$$
\begin{aligned}
\text { fpOC } & =\left(\text { POC }_{\mathrm{p}}-\text { control }\right) \frac{V}{n} \\
\text { DOC } & =\left(\text { DOC }_{\mathrm{p}}\right) \frac{V}{n}, \text { and } \\
\text { POC } & =\left(\text { POC }_{\mathrm{w}}-\text { control }\right) \frac{V}{n}
\end{aligned}
$$

where fpOC is organic carbon still retained in the fecal pellet, DOC is organic carbon originating from fecal pellets dissolved and released to the surrounding water, and POC is particulate organic carbon originating from fecal pellets released to the surrounding water. $V$ is the incubation volume $(10 \mathrm{ml})$, and $n$ is the number of fecal pellets (100). It follows that since these calculations are based solely on ${ }^{14} \mathrm{C}$ originating from the algae on which the copepods had previously fed, these carbon pools represent only carbon originating from the fecal pellets. All contributions of organic carbon from sources other than the fecal pellets themselves are thereby excluded.

Bacterial production. Bacterial production of the fecal pellet and water fractions was measured using the ${ }^{3} \mathrm{H}$-thymidine incorporation technique (Bell 1993). One hour before the end of the incubations, $200 \mu \mathrm{l}$ of $20 \mu \mathrm{M}$ methyl- ${ }^{3} \mathrm{H}$-thymidine (50 $\mathrm{Ci} \mathrm{mmol}{ }^{-1}$ ) was added to the replicates. At the end of the incubations, the samples were fixed with $600 \mu \mathrm{l}$ of $34 \%$ formaldehyde and $10 \mathrm{fe}-$ cal pellets were removed for enumeration of attached bacteria. An aliquot of $4 \mathrm{ml}$ including fecal pellets was taken for production measurement of attached bacteria $\left(b p_{\mathrm{p}}\right)$. Another aliquot of $4 \mathrm{ml}$ not including any fecal material (ascertained at $40 \times$ under the dissecting microscope) was taken for production measurement of free-living bacteria $\left(b p_{\mathrm{w}}\right)$. We added $400 \mu \mathrm{l}$ of $50 \%$ trichloroacetic acid (TCA) to all samples, which were kept on ice for 15 to $60 \mathrm{~min}$, and subsequently filtered through $1 \mathrm{mM}$ thymidine-soaked $0.45 \mu \mathrm{m}$ cellulose acetate filters. Following rinsing with $1 \mathrm{ml}$ ice-cold $5 \%$ TCA $(\times 3)$ and $1 \mathrm{ml}$ ice-cold $80 \%$ ethanol $(\times 5)$, the filters were dissolved in ethyl acetate and counted for isotopic activity using a truncated counting window to minimize interference from ${ }^{14} \mathrm{C}$. Blanks taken at the beginning of the incubation period were treated similarly. Bacterial production rates were calculated according to Bell (1993) using a thymidine conversion factor (TCF) of $2 \times 10^{18}$ cells $\mathrm{mol}^{-1}$. To exclude the contribution from free-living bacteria to the production of attached bacteria, $b p_{\mathrm{w}}$ was subtracted from $b p_{\mathrm{p}}$. Growth rates of attached bacteria were calculated by dividing bacterial production rates by bacterial abundances. Unfortunately we did not measure the abundance of free-living bacteria. The samples for bacterial enumeration were sonicated in $5 \mathrm{ml} 5 \mathrm{mM} \mathrm{Na}_{4} \mathrm{PPi}$ to release the bacteria from the fecal pellets (Velji \& Albright 1993) and counted under an epifluorescence microscope at $1250 \times$ magnification using the acridine orange direct count (AODC) method (Hobbie et al. 1977).

Ectoenzymatic activity. Extracellular enzymatic activity was measured using several different substrates attached to fluorescent markers, either 4-methylumbelliferyl (MUF) or 4-methylcoumarinyl-7-amide (MCA) (Table 1). When they are released from the substrate, the markers become fluorescent by enzymatic cleavage (Hoppe 1993). Fecal pellets from the two 51 beakers (see subsection 'Production and labeling of fecal pellets' above) were pipetted into plastic cuvettes holding 2 ml-filtered LIS water, with 20 fecal pellets in each. The experiments were conducted with 4 replicate fecal pellet samples and 4 replicate filtered LIS water samples of 5 different substrates at a concentration of

Table 1. Cursor-substrate complexes used in ectoenzymatic

\begin{tabular}{|c|c|c|}
\hline Cursor-substrate complex & Substrate & Enzyme \\
\hline MUF- $\alpha$-D-glucopyranoside & Glucogen & $\beta$-glucosidase \\
\hline MUF- $\beta$-D-glucopyranoside & Cellulose & $\beta$-glucosidase \\
\hline MUF-N-acetyl-glucosaminide & Chitin & Glucosaminidase \\
\hline MUF-phosphate & Lipid & Phosphatase \\
\hline MCA-L-leucine & Protein & $\begin{array}{l}\text { Leucine amino- } \\
\text { peptidase }\end{array}$ \\
\hline
\end{tabular}
activity assays. MUF: 4-methylumbelliferyl; MCA: 4-methylcoumarinyl-7-amide 
$75 \mu \mathrm{M}$. The cuvettes were incubated for a total of $96 \mathrm{~h}$. At $0,12,24,48$, and $96 \mathrm{~h}$ the fluorescence of the samples was read in a Hitachi F-2500 fluorescence spectrophotometer. The fluorescence was measured at $364 \mathrm{~nm}$ excitation and $445 \mathrm{~nm}$ emission for MUF and 380 and $440 \mathrm{~nm}$ for MCA. The rate of hydrolysis (nM $\mathrm{h}^{-1}$ ) was calculated according to Hoppe (1993) using standard curves obtained with known concentrations of MUF and MCA standards.

All statistical tests were performed using either StatView 5.01 (SAS Institute) or SigmaStat 2.03 (SPSS).

\section{RESULTS}

The initial masses of the fecal pellets (sum of the fpOC, POC, and DOC pools) were $12.8 \pm 2.1 \mathrm{ng} \mathrm{C}$ pellet $^{-1}$ (mean $\pm \mathrm{SE}$ ) on the diatom Thalassiosira weissflogii diet, $58.3 \pm 19.7 \mathrm{ng} \mathrm{C}$ pellet $^{-1}$ on the cryptophyte Rhodomonas lens diet, and 68.4 $\pm 7.4 \mathrm{ng} \mathrm{C}$ pellet $^{-1}$ on the dinoflagellate Prorocentrum minimum diet. The total amount of organic carbon originating from the pellets (fpOC $+\mathrm{DOC}+\mathrm{POC}$ ) varied during the incubation period. Logically, this should not change by more than what is lost by respiration, since we measured all pools of organic carbon originating from the pellets. The variation was quite high in pellets from the diatom diet (66\% between the highest and lowest value), but lower in pellets from cryptophyte (15\%) and dinoflagellate $(29 \%)$ diets. There was, nevertheless, no significant difference between the total carbon mass at the different sampling points during the incubations on all 3 diets (1-factor ANOVA, $p>0.05)$ and the mean $( \pm \mathrm{SE})$ total carbon masses of the whole incubation periods of $96 \mathrm{~h}$ were almost identical to the initial masses (diatom: $11.7 \pm 1.1 \mathrm{ngC}$ pellet $^{-1}$, cryptophyte: $52.1 \pm 1.0 \mathrm{ng} \mathrm{C}$ pellet $^{-1}$, dinoflagellate: $74.4 \pm 2.8 \mathrm{ng} \mathrm{C}$ pellet $^{-1}$ ).

\section{Decomposition of fecal pellets}

During the $96 \mathrm{~h}$ incubation period, there was no significant decrease in fpOC in pellets from the diatom diet (hereafter called 'diatom pellets') (1-factor ANOVA, p > 0.05; Fig. 1, Table 2). Conversely, decomposition was more pronounced in pellets from the cyptophyte and dinoflagellate diets (hereafter called 'cryptophyte' and 'dinoflagellate pellets'). In cryptophyte pellets, fpOC decreased significantly from 36.9 to $23.1 \mathrm{ng} \mathrm{C}$ pellet $^{-1}$ (1-factor ANOVA: $F=5.24$, $\mathrm{df}=4$, $\mathrm{p}=0.018$ ), and in dinoflagellate pellets it decreased significantly from an initial 38.6 to $19.1 \mathrm{ng} \mathrm{C}$ pellet $^{-1}$ at $96 \mathrm{~h}$ (1-factor ANOVA: $F=7.36, \mathrm{df}=4, \mathrm{p}=0.005)$. The fpOC decrease rates were significantly different between cryptophyte and dinoflagellate pellets (comparison of slopes: Student's $t=2.74, \mathrm{df}=27, \mathrm{p}<0.02$ ).

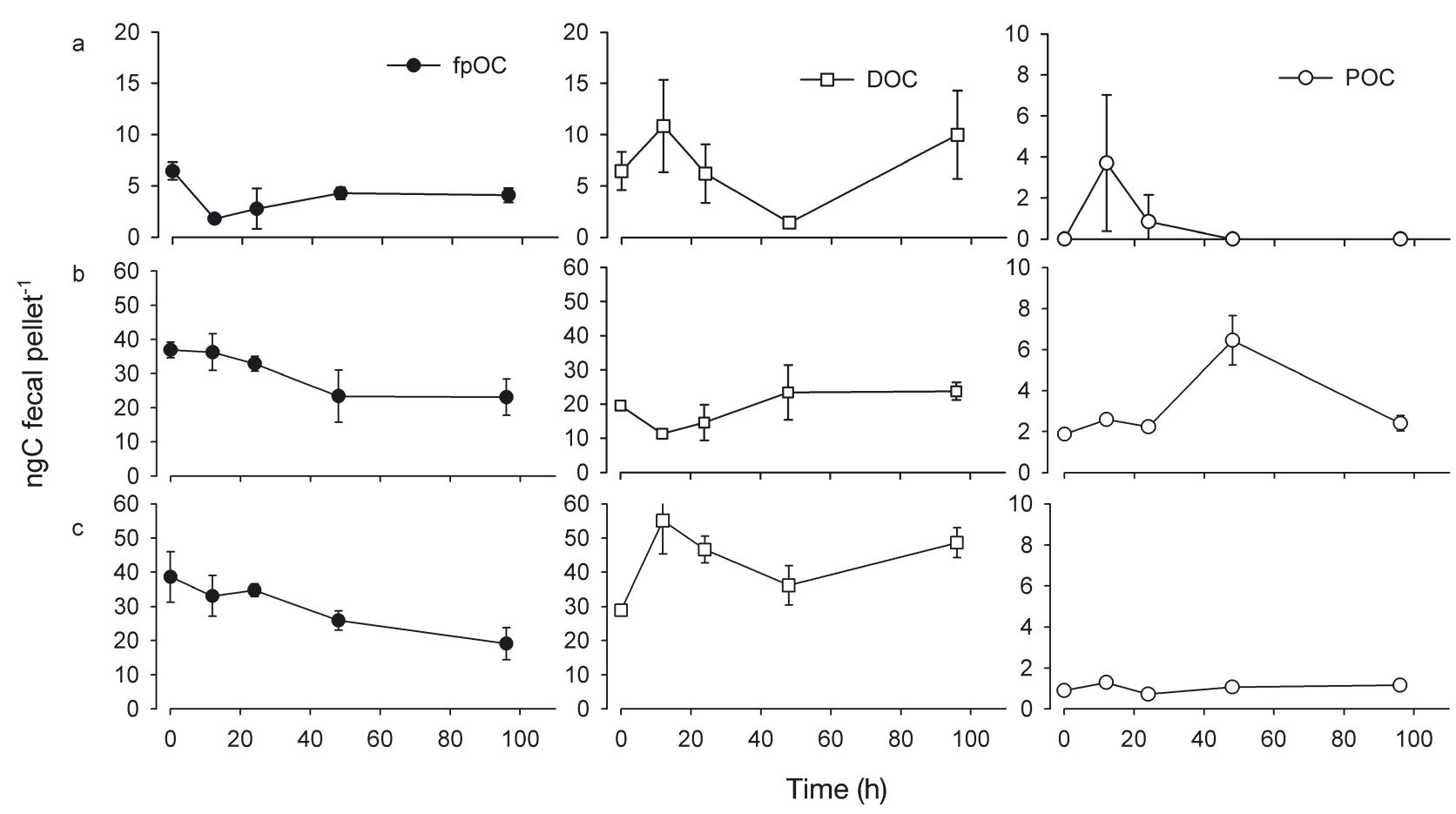

Fig. 1. Carbon content of the 3 pools, fpOC (fecal pellet organic carbon), DOC and POC during the 96 h incubation period. Fecal pellets produced by Acartia tonsa on diets of (a) diatom Thalassiosira weissflogii, (b) cryptophyte Rhodomonas lens, (c) dinoflagellate Prorocentrum minimum. Error bars $=\mathrm{SD} ; \mathrm{n}=3$ 


\section{Fate of released carbon}

The amounts of released DOC were already high at the onset of the incubation period. This was true for all 3 diets, indicating that 50,34 , and $42 \%$ of the total carbon content (fpOC + DOC + POC) had leaked from diatom, cryptophyte, and dinoflagellate pellets at Time $t=0$, i.e. during the initial handling of the pellets. In diatom and dinoflagellate pellets this release continued over the next $12 \mathrm{~h}$. After this initial release, DOC levels decreased on all 3 diets followed by another increase after $48 \mathrm{~h}$ (Fig. 1). The timing of these events was similar for diatom and dinoflagellate pellets, with peak DOC levels after $12 \mathrm{~h}$. For cryptophyte pellets, a peak occurred earlier, at the beginning of the incubation period. However, none of these changes in DOC levels were significant (1-factor ANOVAs: $p$ > 0.15).

The amounts of organic carbon originating from the fecal pellets that were recovered from the POC fractions (POC not including fecal pellets) were low compared to the DOC fractions. Thus, on average over the incubation period, only $6 \%$ of the total organic carbon was recovered as non-pellet POC in diatom pellets, $6 \%$ in cryptophyte pellets, and $1 \%$ in dinoflagellate pellets. Nevertheless, of the total amount of organic carbon released from the pellets (DOC+POC) $25 \%$ of the diatom pellet carbon and $21 \%$ of the cryptophyte pellet carbon were incorporated into non-pellet POC. In cryptophyte pellets the $6.4 \mathrm{ngPOC}$ pellet $^{-1}$ peak at $48 \mathrm{~h}$ was significantly different from the initial level (Kruskal-Wallis 1-factor ANOVA by ranks: $H=9.956$, $\mathrm{df}=4, \mathrm{p}=0.041$ ).

\section{Bacterial production}

Growth rates of attached bacteria ranged from 0.016 to $0.116 \mathrm{~h}^{-1}$, and were highest in diatom and dinoflagellate pellets (Fig. 2). The rates peaked between 24 and $48 \mathrm{~h}$ on all 3 diets, averaging $0.102 \mathrm{~h}^{-1}$ in diatom pellets, $0.047 \mathrm{~h}^{-1}$ in cryptophyte pellets, and $0.116 \mathrm{~h}^{-1}$ in dinoflagellate pellets. Additionally, we found higher production rates at $12 \mathrm{~h}$ in diatom pellets.

Table 2. Carbon decomposition rate (mean $\left.\pm \mathrm{SE}_{;} \mathrm{n}=15\right)$ of fecal pellets produced by Acartia tonsa on the 3 diets. Decomposition rate $(R)$ defined as slope of exponential regression $C=\mathrm{C}_{0} \mathrm{e}^{-R t}$ (Hansen et al. 1996). L-ratio = decomposition rate $R\left(\mathrm{~h}^{-1}\right)$ divided by sinking rate (from Feinberg \& Dam 1998) in $\mathrm{m} \mathrm{h}^{-1}$

\begin{tabular}{|lcccccc|}
\hline \multirow{2}{*}{ Diet } & \multicolumn{3}{c}{ Carbon decomposition } & \multicolumn{2}{c|}{ Half life } & \multicolumn{2}{c|}{$\begin{array}{c}\text { L-ratio } \\
\left(\mathrm{m}^{-1}\right)\end{array}$} \\
& $R\left(\mathrm{~h}^{-1}\right)$ & $\mathrm{r}^{2}$ & $\mathrm{p}$ & $t(\mathrm{~h})$ & ${ }^{2}$ \\
\hline Thalassiosira weissflogii & $0.0038 \pm 0.0048$ & 0.06 & 0.579 & 182 & $2.9 \times 10^{-3}$ \\
Rhodomonas lens & $0.0059 \pm 0.0015$ & 0.59 & 0.010 & 117 & $7.1 \times 10^{-3}$ \\
Prorocentrum minimum & $0.0081 \pm 0.0014$ & 0.77 & $<0.001$ & 85 & $9.7 \times 10^{-3}$ \\
& & & & & \\
\hline
\end{tabular}

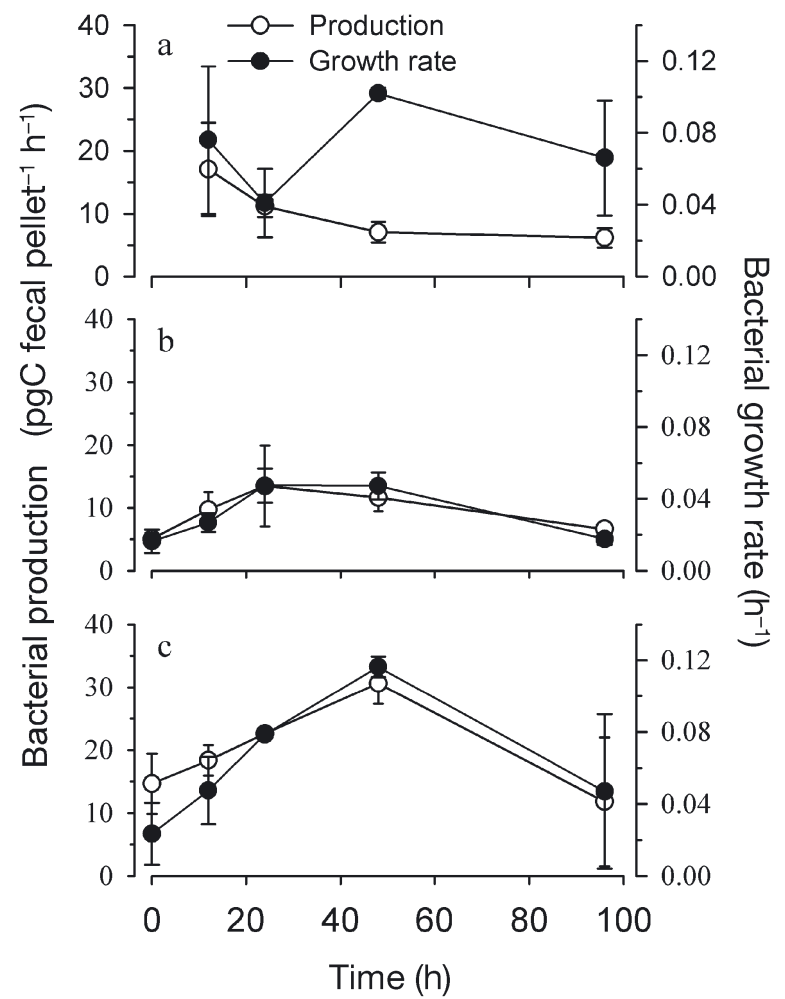

Fig. 2. Production and growth rates of attached bacteria during the $96 \mathrm{~h}$ incubation period on fecal pellets produced by Acartia tonsa on diets of (a) diatom Thalassiosira weissflogii, (b) cryptophyte Rhodomonas lens, (c) dinoflagellate Prorocentrum minimum. Error bars $=\mathrm{SD}_{;} \mathrm{n}=3$

The maximal bacterial production rates were 30.6 pg C pellet ${ }^{-1} \mathrm{~h}^{-1}$ for attached bacteria (Fig. 2) and $867 \mathrm{pg} \mathrm{C} \mathrm{ml}^{-1} \mathrm{~h}^{-1}$ for free-living bacteria (Fig. 3). Average production rates of attached bacteria were 5 orders of magnitude higher than production rates of free-living bacteria in a similar volume of water. In other words, on average, the bacterial production on a single copepod fecal pellet equalled the production of freeliving bacteria occupying a volume of water of $35 \mu \mathrm{l}$.

Production rates of attached bacteria were initially high in diatom pellets (17.1 pg C pellet $\left.{ }^{-1} \mathrm{~h}^{-1}\right)$, but decreased within the first $24 \mathrm{~h}$ to a low rate of $6.2 \mathrm{pg} \mathrm{C}$ pellet $^{-1} \mathrm{~h}^{-1}$ (Fig. 2). The peak in bacterial growth rate at $24 \mathrm{~h}$ did not result in higher production rates. In cryptophyte pellets, the maximal growth rates from 24 to $48 \mathrm{~h}$ induced maximal production rates averaging $12 \mathrm{pgC}$ pellet ${ }^{1-} \mathrm{h}^{-1}$. Production rates of attached bacteria in dinoflagellate pellets peaked similarly

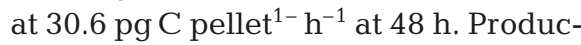
tion rates of attached bacteria were significantly correlated to bacterial growth in cryptophyte and dinoflagel- 


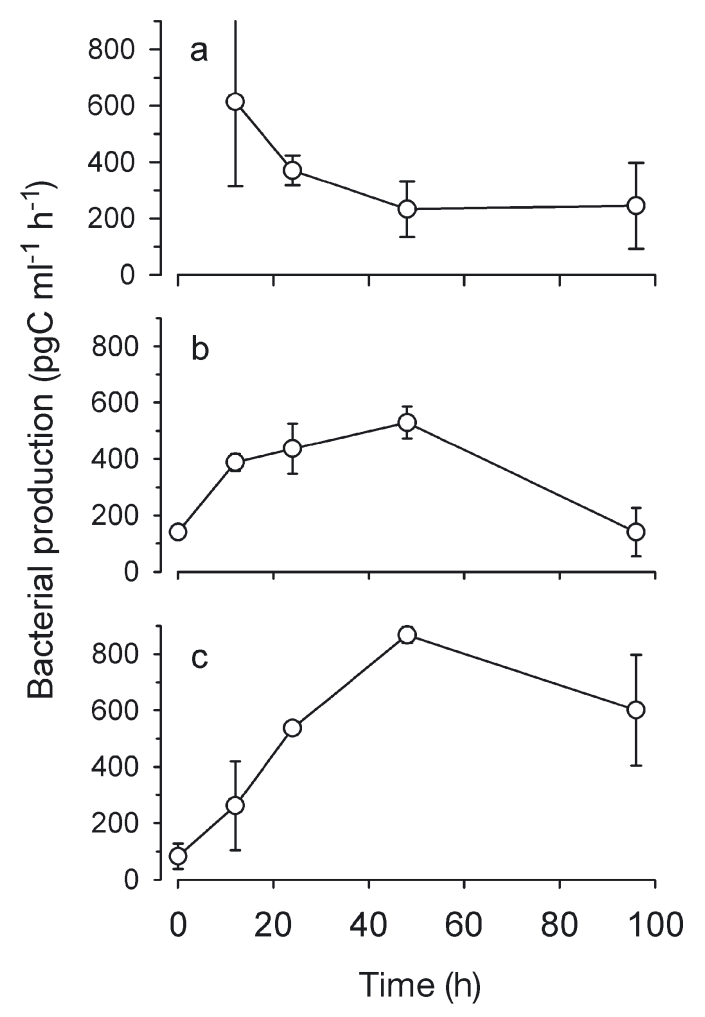

Fig. 3. Production of free-living bacteria during the $96 \mathrm{~h}$ incubation period on fecal pellets produced by Acartia tonsa on diets of (a) diatom Thalassiosira weissflogii, (b) cryptophyte Rhodomonas lens, (c) dinoflagellate Prorocentrum minimum. Error bars $=\mathrm{SD} ; \mathrm{n}=3$

late pellets (Pearson's product-moment correlation: cryptophyte: $\mathrm{r}=0.949, \mathrm{df}=5, \mathrm{p}=0.014$, dinoflagellate: $\mathrm{r}=0.94, \mathrm{df}=5, \mathrm{p}=0.017)$, but not in diatom pellets $(\mathrm{r}=$ $-0.20, \mathrm{df}=4, \mathrm{p}=0.805$ ). There were no correlations between bacterial production and DOC release on any of the 3 diets (Pearson's product-moment correlation: $\mathrm{p}$ > 0.4). Production of free-living bacteria followed the amount of POC originating from diatom and cryptophyte pellets. There was a significant correlation in the cryptophyte pellets but not in the diatom pellets (Spearman's rank-order correlation: cryptophyte: $\mathrm{r}=0.514$, $\mathrm{df}=15, \mathrm{p}=0.048$, diatom: $\mathrm{r}=0.518, \mathrm{df}=11, \mathrm{p}=0.095$ ).

The abundance of attached bacteria ranged from $1.5 \times 10^{4}$ to $4.8 \times 10^{4}$ cells pellet $^{-1}$ (Fig. 4 ). Bacterial production did not induce increases in abundances on any of the diets. In fact, bacterial abundance decreased significantly from 24 to $48 \mathrm{~h}$ in diatom pellets (1-factor ANOVA: $F=7.24, \mathrm{df}=4, \mathrm{p}=0.009$, Student-Newmann-Keuls post-hoc test: $\mathrm{p}=0.012$ ). Bacterial abundances were significantly higher in diatom pellets than in cryptophyte and dinoflagellate pellets (1-factor ANOVA on diets: $F=5.52, \mathrm{df}=2, \mathrm{p}=0.008$, StudentNewmann-Keuls post-hoc test: diatom/cryptophyte: $\mathrm{p}=0.043$, diatom/dinoflagellate: $\mathrm{p}=0.006$ )

\section{Ectoenzymatic activity}

The difference in the rate of ectoenzymatic activity between the fecal pellets and filtered seawater $(\Delta v)$ varied between virtually zero and $278 \mathrm{nM} \mathrm{h}^{-1}$. The activity of all 5 enzymes in the fecal pellets was significantly different from that of filtered LIS water (Figs. 5 \& 6) for all 3 diets (2-factor ANOVA on incubation time between fecal pellets and water, log-transformed data; p-values in Fig. 5). During the incubation period, the activity in the fecal pellets increased in all samples parallel to a similar increase in filtered LIS water, the activity of the LIS water being at some points higher than that of the fecal pellets (negative values of the sum of enzymatic activity $\left[\Delta v_{\text {sum }}\right]$ in Fig. 6$)$. Negative values for $\beta$-glucosidase were recorded on all 3 diets.

There were no significant correlations between ectoenzymatic activity and release of DOC or bacterial production and growth except between the production of attached bacteria and glucosaminidase activity in dinoflagellate pellets (Pearson's product-moment correlation: $\mathrm{r}=0.998, \mathrm{df}=4, \mathrm{p}=0.002$ ).

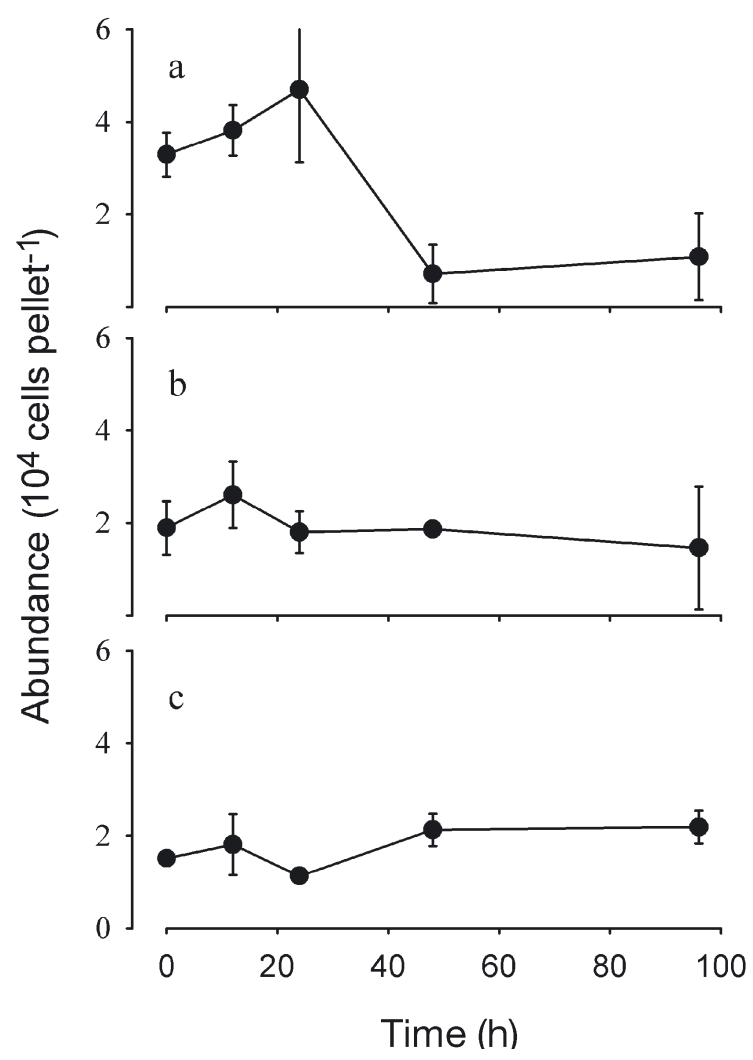

Fig. 4. Abundance of bacteria attached to fecal pellets produced by Acartia tonsa on diets of (a) diatom Thalassiosira weissflogii, (b) cryptophyte Rhodomonas lens, (c) dinoflagellate Prorocentrum minimum. Error bars $=\mathrm{SD} ; \mathrm{n}=3$ 

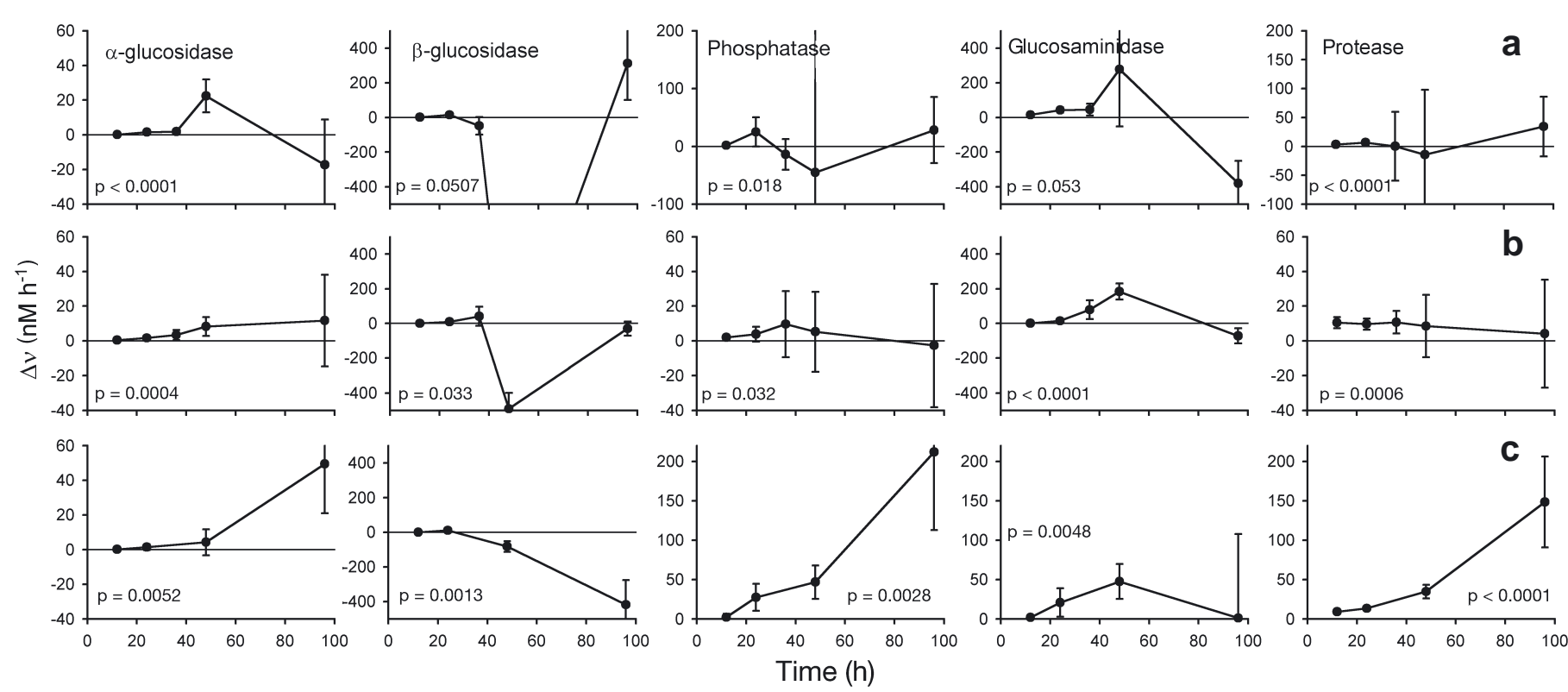

Fig. 5. Difference between rates of ectoenzymatic activities $(\Delta v)$ in filtered seawater and fecal pellets produced by Acartia tonsa on diets of (a) diatom Thalassiosira weissflogii, (b) cryptophyte Rhodomonas lens, (c) dinoflagellate Prorocentrum minimum. p values denote significant differences between log-transformed data from fecal pellets and filtered Long Island Sound (LIS) water. Error bars $=\mathrm{SD} ; \mathrm{n}=4$

\section{DISCUSSION}

Copepod fecal pellets decomposed at rates of 9, 14 and $19 \% \mathrm{~d}^{-1}$ for diatom, for cryptophyte pellets, and for dinoflagellate pellets, respectively. These rates are somewhat higher than those ( 3 to $10 \% \mathrm{~d}^{-1}$ ) reported for Acartia tonsa by Lee \& Fisher (1992). Similarly, fecal pellets produced by zooplankton larger than $200 \mu \mathrm{m}$ and fed a natural assemblage of seston decomposed at a rate of $5 \% \mathrm{~d}^{-1}$ (recalculated from Roy \& Poulet 1990). On the other hand, the decomposition rates in the present study were slightly lower than those found previously for A. tonsa fed comparable diets (Hansen et al. 1996) and for the larger Calanus hyperboreus fed diatoms (Urban-Rich 1999). The initial fecal pellet carbon masses were comparable to those previously reported for fecal pellets of similar size to the ones from our study (Urban-Rich et al. 1998).

The copepod diet had a significant effect on pellet decomposition rates. Diatom pellets decomposed at a significantly lower rate than cryptophyte and dinoflagellate pellets. This contrasts to some extent with the findings of Lee \& Fisher (1992), who found comparably low decomposition rates for fecal pellets of Acartia tonsa fed another diatom, Thalassiosira pseudonana, but who did not find any differences in decomposition rates between diatom and haptophyte pellets. Diatom diets tend to produce dense, rapidly-sinking fecal pellets (Feinberg \& Dam 1998), and in the present study the L-ratio, i.e. the ratio between breakdown rate and sinking speed, was markedly lower for diatom pellets than for cryptophyte or dinoflagellate pellets (Table 2). If our low decomposition rates for diatom pellets are valid, this suggests that copepod grazing and fecal pellet production are potentially more important in the sedimentary carbon flux during diatom blooms. However, coprophagy and coprorhexy by flagellates, ciliates, or copepods may alter degradation rates completely (Gonzalez \& Smetacek 1994, Turner 2002). The low decomposition rate of diatom pellets in our study could have resulted from leakage of organic carbon during the collection of the pellets prior to incubation, biasing the rate estimates negatively. The initial carbon masses of the diatoms pellets were remarkably low

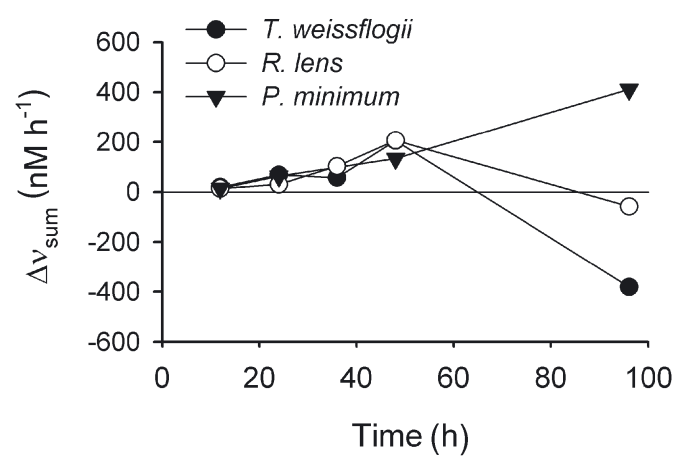

Fig. 6. Sum of ectoenzymatic activities $\left(\Delta v_{\text {sum }}\right)$ of $\beta$-glucosidase, glucosaminidase, phosphatase, and leucine aminopeptidase in fecal pellets produced by Acartia tonsa on all 3 diets. (Thalassiosira weissflogii, Rhodomonas lens, Prorocentrum minimum) 
compared to cryptophyte and dinoflagellate pellets. Nevertheless, we feel confident with the validity of our results, since the diatom pellets appeared smaller in size than the cryptophyte and dinoflagellate pellets. Moreover, lower decomposition rates of diatom pellets have been reported previously (Hansen et al. 1996).

We observed high levels of DOC at the onset of the incubation period for all 3 diets. DOC release continued over the subsequent $12 \mathrm{~h}$ from diatom and dinoflagellate pellets. Leaking of organic carbon from fecal pellets is probably mediated by both physical and biological mechanisms. Initially, soluble compounds trapped inside the pellet matrix may leak passively before the onset of any substantial microbial decomposition. Model calculations have shown that the steep concentration gradient between fecal pellets and the surrounding water would cause the soluble organic matter to passively diffuse out within minutes (Jumars et al. 1989). These calculations have been supported to some extent by recent studies showing substantial DOC leakage from fecal pellets produced by Calanus glacialis and C. finmarchicus within $1 \mathrm{~h}$ of leaving the gut (Møller et al. 2003). Consequently, the amount of fecal pellet DOC that is actually available for attached bacteria is variable. The key factor is the timing of bacterial colonization. If indeed fecal bacteria stem from the copepod gut and the pellets are decomposed from the inside (Gowing \& Silver 1983, Nagasawa \& Nemoto 1988, Delille \& Razouls 1994), then the large DOC release will result in high bacterial production in a matter of hours. This was evident in diatom pellets, for which both growth rates and certainly production rates were initially high. On the other hand, if there are no internal bacteria (Honjo \& Roman 1978), utilization of the initial DOC release by attached bacteria would be very low, and colonization and thus production would occur gradually (Turner \& Ferrante 1979), a scenario resembling that observed for the cryptophyte and dinoflagellate pellets in the present study. After the initial release of DOC, the levels stagnated, possibly as a result of increased uptake due to the onset of attached bacterial production at this time.

The high initial levels of DOC resulted from leakage during the $2 \mathrm{~h}$ handling period prior to the first sampling, but leakage probably also occurred during the 3 to $5 \mathrm{~h}$ collection period prior to the experiments. Since this DOC is not included in our data, the amounts of released DOC reported probably represents minimum levels.

Production rates of attached bacteria varied as a function of their growth rates on the cryptophyte and dinoflagellate diets. Thus, production of new bacterial biomass was an active process on these pellets, and during the $96 \mathrm{~h}$ incubation period bacterial production on fecal pellets produced with the cryptophyte and dinoflagellate diets increased with a timing comparable to what has been found earlier (Jacobsen \& Azam 1984). Con- versely, the initial high bacterial production rates on the diatom diet were caused primarily by high initial abundance, and bacterial growth rates remained low on this diet. Using a growth efficiency of $50 \%$ (Kroer 1993), the bacterial carbon demand was approximately $5 \mathrm{ng} \mathrm{C}$ in diatom and cryptophyte pellets and $10 \mathrm{ng} \mathrm{C}$ in dinoflagellate pellets during the $96 \mathrm{~h}$ incubation period. Thus, the total DOC release was between 3 and 6 times higher than the amount that would be taken up by attached bacteria. The DOC levels were inversely correlated to the production of attached bacteria (although not significantly), so that the peak in bacterial production at 24 to $48 \mathrm{~h}$ generated a decline in DOC levels. The DOC levels measured in the surrounding water was a result of a balance between DOC released by enzymatic activity and DOC assimilated for bacterial production. Therefore, the increased DOC concentrations during the latter part of the incubation period were the result of high enzymatic activity and low production rates of attached bacteria.

The release of DOC may have boosted the growth rates of free-living bacteria, as previously reported for particular aggregates (Unanue et al. 1998). We recovered $25 \%$ of the organic carbon released from the diatom and cryptophyte pellets in the non-pellet POC fraction, which includes free-living bacteria, and correlations showed that $50 \%$ of the variations in the production of free-living bacteria could be explained by variations in incorporation of carbon into the POC fraction. Thus, it appears that decomposition of copepod fecal pellets engenders a large supply of DOC to nonattached microbes and the primary role of attached bacteria in the epipelagic carbon flux is in triggering particle solubilization and the release of DOM, as previously proposed by Cho \& Azam (1988).

In support of this, the production and growth of attached bacteria were more or less uncoupled from the overall ectoenzymatic activity in pellets from all 3 diets. Attached bacteria can exhibit high rates of uptake of e.g., glucose and amino acids (Ayo et al. 2001), despite low thymidine incorporation rates (Kirchman 1983). Since they have low-affinity uptake characteristics adapted to high substrate concentrations (Ayo et al. 2001), a concentrated organic carbon environment such as copepod fecal pellets, might attune their metabolism to production and release of ectoenzymes rather than to growth. Thus, despite higher production rates, growth rates of attached bacteria could be lower than those of free-living bacteria (Alldredge et al. 1986). Unfortunately we did not measure the abundance of free-living bacteria and could make no comparison. Since the average production rates of attached bacteria were 5 orders of magnitude higher than the production rates of free-living bacteria in a similar volume of water, it would appear that cope- 
pod fecal pellets - at least on the basis of production are microbial hot spots. Nevertheless, this high production may have been due solely to higher bacterial abundance, and we did not record growth rates for bacteria that were confidently higher than those reported for free-living bacteria by Unanue et al. (1998). It thus appears that the high ectoenzymatic activity associated with the fecal pellets enhanced release of DOC rather than growth of attached bacteria, similar to the situation for amorphous aggregates (Smith et al. 1992). This appears to be a general trait of attached bacteria in the pelagic environment, leading to release of DOM from sinking particles (Cho \& Azam 1988, Karner \& Herndl 1992, Unanue et al. 1998).

The activity of glucosaminidase, which catalyzes the hydrolysis of chitin, increased manyfold, reaching a maximum at $48 \mathrm{~h}$ on all 3 diets and was, in contrast to the activity of all other enzymes tested, fairly well coupled to the production of attached bacteria. A host of different chitin-hydrolyzing bacteria is present in the marine environment (Osawa \& Koga 1995, Kirchman \& White 1999). The peritrophic membrane surrounding fecal pellets consists of chitin, and its breakdown appears to be facilitated by high hydrolytic activity. Microscopic inspection of decaying fecal pellets has revealed that the peritrophic membrane can rupture within $3 \mathrm{~h}$ and be completely broken down within $24 \mathrm{~h}$ (Honjo \& Roman 1978). In the present study, hydrolysis of chitin ceased after $48 \mathrm{~h}$, possibly due to complete decomposition of the membrane. Bacterial production on pellets produced by the cryptophyte and dinoflagellate diets correlated relatively well with the glucosaminidase activity (significantly so in dinoflagellate pellets). Thus, chitin may play an important role in bacterial production associated with copepod fecal pellets. Certainly, hydrolysis of chitin has been shown to support a substantial part of estuarine bacterial production (Kirchman \& White 1999).

Production of attached bacteria did not result in increased bacterial abundances on the fecal pellets. Since bacteria show a range of different strategies for reversible attachment and release from surfaces (Marshall 1996), the uncoupling of bacterial production and abundance could be attributable to newly produced bacterial cells being released from the fecal pellets. We did in fact observe a decrease in bacterial abundance on fecal pellets from the diatom diet. Similar theories on cell export have been put forward by Jacobsen \& Azam (1984), whose study showed that $>90 \%$ of the attached bacteria were released from copepod fecal pellets. Sediment trap studies have revealed a paradoxical relationship between a decrease in POM flux down through the water column and a decrease in attached microbial biomass (Karl et al. 1988), whereas if the decomposition of particles is mediated by microbial breakdown, one whould expect increasing microbial biomass with increasing breakdown of the sinking particles. This paradox could be partly due to a continual removal of bacterial cells, which have been produced on and have taken part in the decomposition of the sinking particles, similar to the situation that we believe took place in the fecal pellets in the present study.

Acknowledgements. We would like to thank Dr. S. P. Colin for many useful suggestions on the design of the experiments and Dr. G. B. McManus for help with the bacterial production method. P. Thor was supported by the Danish Natural Science Research Council (grant \#51-00-0415) and the European Commission (contract \#HPMF-CT-2000-01110). H. G. Dam was supported by NSF grant \#OCE-9521907 (USA).

\section{LITERATURE CITED}

Alldredge AL, Cole JJ, Caron DA (1986) Production of heterotrophic bacteria inhabiting macroscopic organic aggregates (marine snow) from surface waters. Limnol Oceanogr 31:68-78

Ayo B, Unanue M, Azua I, Gorsky G, Turley C, Iriberri J (2001) Kinetics of glucose and amino acid uptake by attached and free-living marine bacteria in oligotrophic waters. Mar Biol 138:1071-1076

Ayukai T, Hattori H (1992) Production and downward flux of zooplankton fecal pellets in the anticyclonic gyre off Shikoku, Japan. Oceanol Acta 15:163-172

Bathmann UV, Noji TT, Voss M, Peinert R (1987) Copepod fecal pellets - abundance, sedimentation and content at a permanent station in the Norwegian Sea in May/June 1986. Mar Ecol Prog Ser 38:45-51

Bell RT (1993) Estimating production of heterotrophic bacterioplankton via incorporation of tritiated thymidine. In: Kemp PF, Sherr PF, Sherr BF, Cole JJ (eds) Handbook of methods in aquatic microbial ecology. Lewis Publishers, Boston, MA, p 495-503

Besiktepe S, Dam HG (2002) Coupling of ingestion and defecation as a function of diet in the calanoid copepod Acartia tonsa. Mar Ecol Prog Ser 229:151-164

Bianchi M, Marty D, Fowler SW (1992) Strictly aerobic and anaerobic bacteria associated with sinking particulate matter and zooplankton fecal pellets. Mar Ecol Prog Ser 88:55-60

Cho BC, Azam F (1988) Major role of bacteria in biogeochemical fluxes in the oceans interior. Nature 332:441-443

Dam HG, Peterson WT (1988) The effect of temperature on the gut clearance rate constant of planktonic copepods. J Exp Mar Biol Ecol 123:1-14

Delille D, Razouls S (1994) Community structures of heterotrophic bacteria of copepod fecal pellets. J Plankton Res 16:603-615

Feinberg LR, Dam HG (1998) Effects of diet on dimensions, density and sinking rates of fecal pellets of the copepod Acartia tonsa. Mar Ecol Prog Ser 175:87-96

Fowler SW, Small LF, Larosa J (1991) Seasonal particulate carbon flux in the coastal Northwestern Mediterranean Sea, and the role of zooplankton fecal matter. Oceanol Acta 14:77-85

Gonzalez HE, Smetacek V (1994) The possible role of the cyclopoid copepod Oithona in retarding vertical flux of zooplankton fecal material. Mar Ecol Prog Ser 113: 233-246 
Gonzalez HE, Gonzalez SR, Brummer GJA (1994) Short-term sedimentation pattern of zooplankton, faeces and microplankton at a permanent station in the Bjørnafjorden (Norway) during April-May 1992. Mar Ecol Prog Ser 105: 31-45

Gowing MM, Silver MW (1983) Origins and microenvironments of bacteria mediating fecal pellet decomposition in the sea. Mar Biol 73:7-16

Guillard RRL, Ryther JH (1962) Studies of marine planktonic diatoms. I. Cyclotella nana Hustedt and Detomula confervacea Cleve. Can J Microbiol 8:229-239

Hansen B, Bech G (1996) Bacteria associated with a marine planktonic copepod in culture. I. Bacterial genera in seawater, body surface, intestines, and fecal pellets and succession during fecal pellet degradation. J Plankton Res 18:257-273

Hansen B, Fotel FL, Jensen NJ, Madsen SD (1996) Bacteria associated with a marine planktonic copepod in culture. II. Degradation of fecal pellets produced on a diatom, a nanoflagellate or a dinoflagellate diet. J Plankton Res 18: 275-288

Hobbie JE, Daley RJ, Jasper S (1977) Use of Nuclepore filters for counting bacteria by fluorescence microscopy. Appl Environ Microbiol 33:1225-1228

Honjo S, Roman MR (1978) Marine copepod fecal pellets: production, preservation, and sedimentation. J Mar Res $36: 45-57$

Hoppe HG (1993) Use of fluorogenic model substrates for extracellular enzyme activity (EEA) measurement of bacteria. In: Kemp PF, Sherr PF, Sherr BF, Cole JJ (eds) Handbook of methods in aquatic microbial ecology. Lewis Publishers, Boston, MA, p 423-431

Jacobsen TR, Azam F (1984) Role of bacteria in copepod fecal pellet decomposition-colonization, growth-rates and mineralization. Bull Mar Sci 35:495-502

Jumars PA, Penry DL, Baross JA, Perry MJ, Frost BW (1989) Closing the microbial loop - dissolved carbon pathway to heterotrophic bacteria from incomplete ingestion, digestion and absorption in animals. Deep-Sea Res Part A Oceanogr Res Pap 36:483-495

Karl DM, Knauer GA, Martin JH (1988) Downward flux of particulate organic-matter in the ocean-a particle decomposition paradox. Nature 332:438-441

Karner M, Herndl GJ (1992) Extracellular enzymatic activity and secondary production in free-living and marinesnow-associated bacteria. Mar Biol 113:341-347

Kirchman D (1983) The production of bacteria attached to particles suspended in a freshwater pond. Limnol Oceanogr 28:858-872

Kirchman DL, White J (1999) Hydrolysis and mineralization of chitin in the Delaware Estuary. Aquat Microb Ecol 18: $187-196$

Kroer N (1993) Bacterial growth efficiency on natural dissolved organic matter. Limnol Oceanogr 38:1282-1290

Landry MR, Lorenzen CJ, Peterson WK (1994) Mesozooplankton grazing in the southern California Bight: II. Grazing impact and particulate flux. Mar Ecol Prog Ser 115:73-85

Lane PVZ, Smith SL, Urban JL, Biscaye PE (1994) Carbon flux and recycling associated with zooplanktonic fecal pellets on the shelf of the Middle Atlantic Bight. Deep-Sea Res Part II Top Stud Oceanogr 41:437-457

Lee BG, Fisher NS (1992) Decomposition and release of elements from zooplankton debris. Mar Ecol Prog Ser 88: $117-128$

Legendre L, Michaud J (1998) Flux of biogenic carbon in oceans: size-dependent regulation by pelagic food webs.
Mar Ecol Prog Ser 164:1-11

Lundsgaard C, Olesen M (1997) The origin of sedimenting detrital matter in a coastal system. Limnol Oceanogr 42: 1001-1005

Marshall KC (1996) Adhesion as a strategy for access to nutrients. In: Fletcher M (ed) Bacterial adhesion. Wiley \& Sons, New York, p 59-87

Møller EF, Thor P, Nielsen TG (2003) Production of DOC by Calanus finmarchicus, C. glacialis and C. hyperboreus through sloppy feeding and leakage from fecal pellets. Mar Ecol Prog Ser 262:185-191

Nagasawa S, Nemoto T (1988) Presence of bacteria in guts of marine crustaceans and on their fecal pellets. J Plankton Res 10:559-564

Nielsen MV, Olsen Y (1989) The dependence of the assimilation efficiency in Daphnia magna on the ${ }^{14} \mathrm{C}$-labeling period of the food algae Scenedesmus acutus. Limnol Oceanogr 34:1311-1315

Osawa R, Koga T (1995) An investigation of aquatic bacteria capable of utilizing chitin as the sole source of nutrients. Lett Appl Microbiol 21:288-291

Roy S, Poulet SA (1990) Laboratory study of the chemical composition of ageing copepod fecal material. J Exp Mar Biol Ecol 135:3-18

Roy S, Silverberg N, Romero N, Deibel D and 6 others (2000) Importance of mesozooplankton feeding for the downward flux of biogenic carbon in the Gulf of St. Lawrence (Canada). Deep-Sea Res Part II Top Stud Oceanogr 47: $519-544$

Smith DC, Simon M, Alldredge AL, Azam F (1992) Intense hydrolytic enzyme-activity on marine aggregates and implications for rapid particle dissolution. Nature 359: 139-142

Strathmann RR (1967) Estimating the organic carbon content of phytoplankton from cell volume or plasma volume. Limnol Oceanogr 12:411-418

Turner JT (2002) Zooplankton fecal pellets, marine snow and sinking phytoplankton blooms. Aquat Microb Ecol 27: 57-102

Turner JT, Ferrante JG (1979) Zooplankton fecal pellets in aquatic ecosystems. BioScience 29:670-677

Unanue M, Azua I, Arrieta JM, Labirua-Iturburu A, Egea L, Iriberri J (1998) Bacterial colonization and ectoenzymatic activity in phytoplankton-derived model particles: cleavage of peptides and uptake of amino acids. Microb Ecol 35:136-146

Urban-Rich J (1999) Release of dissolved organic carbon from copepod fecal pellets in the Greenland Sea. J Exp Mar Biol Ecol 232:107-124

Urban-Rich J, Hansell DA, Roman MR (1998) Analysis of copepod fecal pellet carbon using a high temperature combustion method. Mar Ecol Prog Ser 171:199-208

Velji MI, Albright LJ (1993) Improved sample preparation for enumeration of aggregated aquatic substrate bacteria. In: Kemp PF, Sherr PF, Sherr BF, Cole JJ (eds) Handbook of methods in aquatic microbial ecology. Lewis Publishers, Boston, MA, p 139-142

Viitasalo M, Rosenberg M, Heiskanen AS, Koski M (1999) Sedimentation of copepod fecal material in the coastal northern Baltic Sea: where did all the pellets go? Limnol Oceanogr 44:1388-1399

Wassmann P, Hansen L, Andreassen IJ, Riser CW, Urban-Rich J (1999) Distribution and sedimentation of faecal pellets on the Nordvestbanken shelf, northern Norway, in 1994. Sarsia 84:239-252

Wotton RS, Malmqvist B (2001) Feces in aquatic ecosystems. BioScience 51:537-544

Submitted: February 21, 2003; Accepted: June 20, 2003

Proofs received from author(s): October 7, 2003 